\title{
EDITORIAL
}

\section{POESIA EM PERFORMANCES URBANAS}

O discurso poético é, em essência, performativo, uma vez que institui um ato de fala em que a linguagem per se - e não sua função comunicativa pragmática - ocupa o primeiro plano. Como explica Jonathan Culler, a poesia é performativa porque cria e organiza pela linguagem um mundo, "em lugar de simplesmente representar o que existe". Mas, para além desse sentido genérico de performatividade, uma vigorosa vertente da poesia contemporânea tem sido pensada, apresentada e fruída como evento performativo, nos quais o texto verbal se materializa por meio da expressividade vocal, gestual e corporal do artista-poeta, e é comunicado ao vivo a um grupo de espectadores.

Confluindo com tendências contemporâneas da arte dramática, happenings, pixo e instalações artísticas, eventos ao vivo de poesia como saraus e slams têm ocupado espaços diversos de grandes e pequenas cidades, transformando a expressão literária em experiência sincrônica coletiva, mediada pela oralidade e escuta. Nesse movimento, tais eventos revolucionam o próprio conceito de literatura e desconstroem noções e valores que se formaram em torno da primazia de longa duração da cultura impressa, da produção literária como atividade solitária e da leitura como prática individual e silenciosa. Além disso, podem, de forma programada ou não, cumprir outras diversas funções, desde a ressignificação e revitalização de lugares públicos, até a descentralização e democratização do acesso à produção e recepção de bens simbólicos.

De fato, ao franquearem a participação a qualquer pessoa interessada, saraus e slams driblam barreiras econômicas, sociais, raciais, culturais e geográficas que restringem o alcance que a literatura pode ter

CULLER, Jonathan. Teoria literária: uma introdução. Tradução Sandra Vasconcelos. São Paulo: Beca Produções Culturais, 1999. p. 101. 
em um país como o Brasil. Consequentemente, ampliam os canais de recepção de literatura e promovem a emergência de vozes autorais mais diversificadas. Muitos desses eventos poéticos, como se sabe, ocorrem em áreas periféricas ou marginalizadas, sendo organizados e frequentados prioritariamente pelos membros de comunidades menos privilegiadas ou gravemente desassistidas. Entende-se, assim, por que saraus e slams se constituíram como importantes canais de reflexão política e de afirmação de identidades periféricas ou marginais. Os textos/performances aí apresentados elaboram e compartilham potentes discursos contrahegemônicos, de defesa de direitos e de denúncia de abusos e injustiças. Promovem tanto o lazer quanto processos de subjetivação, socialização e ativismo político e cultural. Nesse sentido, os eventos de poesia nas áreas marginalizadas oferecem uma marginalidade "pela qual se opta como espaço de resistência”, como sugere bell hooks: “[e]ssa marginalidade oferece a uma pessoa a possibilidade de ter uma perspectiva radical a partir da qual possa ver e criar, imaginar alternativas, criar novos mundos"2. A partir de vários tipos de margens - econômicas, raciais, de gênero - saraus e slams ajudam a desconstruir estigmas e revitalizam a lírica através da performance, da comunicação direta com o público, do restabelecimento do vínculo comunitário e da catarse através da palavra poética.

Para investigar os caminhos, possibilidades e impactos da disseminação de eventos poéticos ao vivo pelas cidades brasileiras, este número da Texto Poético apresenta o dossiê Poesia em performances urbanas.

O dossiê é aberto com o artigo "Slam Surdo: análise das dimensões políticas e poéticas na performance 'O mudinho', de Edinho Santos”, escrito por Wanderlina Maria de Sousa Araújo, Fábio Vieira de Souza Júnior e Vinicius Carvalho Pereira. Abarcando uma dimensão praticamente inexplorada no debate acadêmico sobre o slam poetry, o texto formula uma análise crítica da performance em Libras "O mudinho", apresentada por Edinho Santos no SLAM SP, contando também com a interpretação simultânea para o português feita por James Bantu. A investigação

HOOKS, bell. Anseios: raça, gênero e políticas culturais. São Paulo: Elefante, 2019. p. 289 
mostra-se atenta aos elementos verbais e não verbais que singularizam a performance em Libras, uma língua gestual-visual, bem como às questões de representatividade, afirmação identitária e crítica social presentes na obra de Edinho Santos.

Na sequência, contamos com o artigo "Sarau da gruta: arte como espaço de criação, fruição e sociabilidade”, de Débora Duarte dos Santos e Ricardo Flores Vidal. O trabalho faz um breve histórico deste importante coletivo cultural da cena paulista, demarcando suas estratégias de divulgação da poesia, especialmente a partir de performances nas quais o diálogo com o hip hop, as artes plásticas e a dança é explorado com grande vigor. Por fim, a relação visceral do coletivo com a urbe paulistana é explorada por meio da leitura dos poemas "VoraCidade" e "Augusta", cuja interpretação crítica nos permite compreender o alto grau de experimentação das performances poéticas do Sarau da Gruta, como parte do contexto de uma cultura híbrida e contra-hegemônica, cuja identidade se funda através da articulação de culturas urbanas da contemporaneidade.

Em "Das vozes insurgentes no movimento Poetry Slam à reexistência do Slam das Minas: a estética da poesia da quebrada pelas manas, monas e monstras", Patrícia Pereira da Silva e Paulo Eduardo Benites de Moraes propõe uma análise de dois poemas publicados no livro Querem nos calar: poemas para serem lidos em voz alta (2019), organizado por Mel Duarte e que reúne poemas de slammers, sobretudo apresentados anteriormente nos Slams das Minas. Os poemas escolhidos para uma leitura atenta são “Garganta”, de Roberta Estrela D’Alva, e "Aquela que não te pertence”, de Bell Puã, ambos analisados sob a luz das reflexões sobre subjetividade lírica e representação social elaboradas por Jacques Rancière e Roberto Zular.

O dossiê é finalizado com o artigo "Reflexões sobre a poesia slam: a coisa tá preta, de Felipe Marinho”, de Aline Camara Zampieri e Mariely Zambianco Soares Sousa. O texto faz um balanço crítico da introdução da poesia slam no Brasil, refletindo sobre a relevância da temática étnicoracial, o racismo, a negritude e o empoderamento negro nessa produção. 
O poema de Felipe Marinho, que ocupa o centro da análise, evidencia a vocação anticanônica e socialmente questionadora dessas poéticas.

Na seção Vária contamos também com quatro trabalhos, abarcando distintos temas de interesse para o estudo da poesia.

Em "Ilustrado com texto: um estudo sobre Aniki Bóbó, de Aloisio Magalhães e João Cabral de Melo Neto”, Fábio José Santos de Oliveira desenvolve uma minuciosa discussão sobre Aniki Bóbó, um livro pouco conhecido de João Cabral de Melo Neto feito em parceria com o artista plástico e designer Aloisio Magalhães. A investigação de Oliveira esclarece diversos pontos da estrutura do livro, destacando o caráter lúdico por trás de sua composição, mas também os indícios que o integram à poética cabralina mais conhecida, especialmente por meio da construção da imagem artística e no diálogo com as artes plásticas.

Em "Escrever do corpo, o corpo da poesia: corporeidades poéticas em Maria Teresa Horta”, José Rosa dos Santos Júnior examina as corporeidades poéticas que se forjam no âmbito da poética de Maria Teresa Horta, com ênfase no livro Palavras Secretas (2007). Conhecida por sua escrita empenhada na construção de uma estética feminina e feminista, Maria Teresa Horta é abordada, no artigo, como uma poeta que atravessa as questões de gênero, tecendo uma rede conceitual e metafórica que repensa continuamente o corpo, o desejo e a violência contra a mulher.

Abordando também a lírica portuguesa mais recente temos o trabalho "Considerações sobre a poesia portuguesa contemporânea: leitura de quatro poetas”, de Goiandira Ortiz de Camargo. No artigo, a autora apresenta algumas configurações da lírica portuguesa contemporânea, a partir da leitura de poemas de Manuel de Freitas, Ana Luísa Amaral, José Tolentino Mendonça e Maria do Rosário Pedreira. A análise recorre às noções de poesia "de mais" e poesia "de menos", postuladas por Amaral (1991), para compreensão da lírica contemporânea. A essas duas categorias, a autora acrescenta uma terceira chave de leitura, que propõe como síntese das duas.

Encerrando o número, temos o artigo de Wesley Thales de Almeida Rocha, intitulado "Dentro da cidade nua e veloz: a criação poética em 
meio às tensões do espaço urbano, na obra poética de Ferreira Gullar”. Ele aborda o fazer poético em meio às tensões da vida urbana como marca fundamental da obra lírica de Ferreira Gullar. Assim, defende que cidade, especialmente a rua, torna-se, nessa poesia, um espaço primordial da experiência poética e da política. Isso porque o sujeito lírico se depara com os signos do capitalismo a ameaçarem a sua subjetividade e a sua relação com o outro, marcando o poema com uma forte carga crítica, vincada junto à complexa teia social que caracteriza a polis moderna.

Acreditamos que a qualidade dos artigos reunidos neste número, aliada à diversidade de objetos e métodos de leitura, evidenciam um crescente interesse crítico por essa faceta da lírica contemporânea. Assim, os resultados de pesquisa aqui apresentados certamente estimulam um debate mais amplo e contribuirão com muitas investigações quem vêm sendo realizadas, na universidade e para além dela, sobre essa produção. Desejamos a todos e todas uma ótima leitura!

Carlos Cortez-Minchillo ${ }^{3}$

Marcelo Ferraz ${ }^{4}$

(Organizadores de Dossiê)

3 Professor Associado no departamento de Espanhol e Português de Dartmouth College, New Hampshire, EUA. E-mail: minchillo@dartmouth.edu Orcid iD: https://orcid. org/0000-0002-2970-1076

4 Professor Adjunto do Departamento de Estudos Literários da Universidade Federal de Goiás/UFG, Goiânia, Goiás, Brasil. E-mail: marcelo2867@ufg.br Orcid iD: https://orcid. org/0000-0003-4728-2976 